\title{
International tax transparency and Least Developed Countries
}

Rod Michelmore

\section{Introduction}

The 46 Least Developed Countries are home to over 1 billion people, most of whom live in poverty. The severe structural handicaps of these countries are such that their governments are the least likely to be able to mobilise the domestic tax revenues required to realise minimum essential socioeconomic rights. The large scale of cross-border tax evasion by high-net-worth individuals (HNWIs) and aggressive tax avoidance by multinational enterprises (MNEs) in many Least Developed Countries raises urgent international human rights law considerations concerning the deficit of international cooperation to detect the widespread misuse of the international financial system - that drains the revenues of those governments with primary responsibility for fulfilling the rights of most people living in extreme poverty.

This interface between international tax law and international human rights law has generated a growing body of literature (International Bar Association 2013; Beckett 2018; Alston and Reisch 2019). In particular, the magnitude of offshore revenue leakage from developing countries has prompted analysis across a wide range of international tax law issues, including: inequitable allocation of taxing rights between developed and developing countries; asymmetrical bilateral treaties that subvert domestic taxation; and most notably inadequate international cooperation to methodically identify concealed cross-border tax evasion and aggressive tax avoidance from developing countries.

The failure of global economic policymakers and standard setting bodies to adequately address the impact of offshore financial secrecy on the administration and enforcement of revenue laws in developed and developing countries has prompted the most extensive critical examination. Calls for reform have included: international conventions (Norwegian Government Commission 2009, p. 13; Etter-Phoya et al. 2019), global registries (Independent Commission for the Reform of International Corporate Taxation 2019, p. 13; Zucman 2015, p. 92) and even the outlawing of tax havens (de Zayas 2016, p. 27). Notwithstanding mounting concerns regarding the negative impacts of offshore financial secrecy, the outcomes of past UN Financing for Development Conferences hold out little prospect of forging an international political coalition for innovative across-the-board international tax transparency reform.

This chapter takes a more nuanced approach towards the international transparency standards that regulate offshore financial secrecy, by focussing on their impact on the Least Developed 
Countries. It examines the opportunities for international human rights law and the 2030 Agenda for Sustainable Development (2030 Agenda) to bring about reform of international tax transparency standards that have marginalised the Least Developed Countries in crucial areas such as the automatic exchange of tax-related information. Specifically, it considers their scope to advance a human rights-based approach towards unchecked financial flows from low-income countries, within a bifurcated framework of international tax transparency cooperation.

With three quarters of Least Developed Countries in sub-Saharan Africa (referred to here as Africa), it is projected that the region will be home to $90 \%$ of the world's poorest people by the end of the decade (Kharas et al, 2018). Yet, Africa currently loses more in illicit financial flows (IFFs) than it receives in overseas aid - making it a net creditor to the world (United Nations Economic Commission for Africa (UNECA) 2015, p. 2). Despite estimates of IFFs from Africa ranging from US\$50-80 billion annually (Global Forum on Transparency and Exchange of Information for Tax Purposes 2020, p. 7); the one-size-fits-all approach of the international transparency standards that regulate cross-border financial flows has largely overlooked the structural handicaps and urgent needs of Africa's Least Developed Countries, none of which automatically receive tax-related information.

Cross-border tax evasion and aggressive tax avoidance (tax-related IFFs) from Least Developed Countries are more likely to go unchallenged when transparency standards allow such misuse of the international financial system to remain concealed. This may lead to foreseeable human rights violations for those who rely upon Least Developed Country governments to fulfil core socioeconomic rights. Those violations can, inter alia, be indirectly attributed to states that exercise authority and control over the global standards that determine whether core offshore financial information on non-residents, and corporate reporting information on MNEs in each jurisdiction where they do business, is actually made available to the Least Developed Countries to administer and enforce their revenue laws (core transparency information).

The political commitments that launched the developmental concept of IFFs in 2015 offer a singular practical opportunity to address the harms that unchecked international financial flows can cause to those in the poorest countries. The Third International Conference on Financing for Development in Addis Ababa stressed the urgent need to address IFFs from developing countries; resolving that future international tax cooperation should fully take into account the different needs and capacities of all countries - in particular Least Developed Countries (United Nations 2015, para. 24). Later that year the 2030 Agenda in New York resolved at the highest political level to significantly reduce IFFs (United Nations General Assembly (UNGA) 2015, SDG 16.4).

Yet, global policy actions on IFFs continue to lag behind political rhetoric to address misuse of the international financial system (United Nations 2020, p. 38). The resulting schism between international tax law and international human rights law can be explained by various political, economic and ideological factors. A crucial technical barrier to their congruence has been the challenge of defining and measuring cross-border tax evasion and aggressive tax avoidance. Delimiting these cross-border practices that illicitly drain public revenues is critical to linking the international tax transparency standards that allow unchecked financial flows from the Least Developed Countries, to the manifest human rights violations of their peoples.

International development forums, specifically the 2030 Agenda, provide a political framework to address this longstanding quandary. The UN General Assembly in settling the parameters to measure tax-related IFFs will enable such misuse of the international financial system to be juxtaposed with Sustainable Development Goals (SDGs) in key areas like education, health and housing. This opens the way to establishing a correlation between the regulatory standards that determine how international capital engages with systemically disadvantaged low-income countries, and their abilities to realise minimum essential socioeconomic rights. 


\section{Extraterritorial obligations of states}

International human rights law jurisprudence has conventionally focused on the conduct of states towards their own peoples. However, it is increasingly recognised that when states conduct themselves in a way that has foreseeable effects on human rights in other jurisdictions, they must ensure they respect and protect those rights. In certain situations, these extraterritorial obligations (ETOs) may require states to fulfil the rights of those living beyond their borders.

Economic globalisation has contributed to a states of affairs in which impairment of socioeconomic rights in other territories is more likely to be caused by 'externalities' from national laws, policies and practices - than the conduct of state organs that are physically present on foreign soil (Askin 2019). The idea of invoking socioeconomic human rights obligations against states other than the territorial state emerged around the turn of the millennium, and has gained transformative momentum since then (Peters 2018, p. 302). However, such progressive interpretations of international human rights law aren't universally accepted within the academy, and it has proven difficult to put these ideas into practice.

The conventional pathways used to entrench ETOs involving civil and political human rights are generally not available for clarifying state duties regarding socioeconomic rights. Moreover, governments in most advanced economies have been unwilling to recognise legally binding socioeconomic ETOs, given their potential to require the redistribution of states' resources. That said, the globalisation process has fundamentally shifted the human rights focus from 'government' to 'governance' - diversifying the number and range of actors that could be regarded as impacting the enjoyment of human rights in other territories (Vandenhole and Benedek 2013, p. 332).

This chapter examines the scope for integrating emerging legal doctrines concerning the extraterritorial application of socioeconomic rights into the international standards that determine whether Least Developed Countries receive core transparency information from the global network of over 80 jurisdictions seeking to attract internationally mobile capital (offshore states). The salient international human rights law obligations of states in this all-important aspect of global economic governance are rooted in the International Covenant on Economic Social and Cultural Rights (United Nations 1966).

In considering how international law determines the way that states act, it is important to distinguish the law of jurisdiction in general international law, which is about 'entitlements to act'; from the law of state responsibility, which is about 'obligations incurred when a state does act' (Higgins 1995, p. 146). In that sense, it may be argued that in certain circumstances the international human rights law obligations of states can operate as a check on the exercise of their otherwise sovereign powers to regulate those under their effective control.

The legal ramifications of the international human rights law obligations undertaken by states have been distilled into the Maastricht Principles on Extraterritorial Obligations of States in the Area of Economic, Social and Cultural Rights - which offer a progressive interpretation of the diverse jurisprudence in this nascent area of international law. The Maastricht Principles' approach towards jurisdiction stipulates that a state has obligations to respect, protect and fulfil socioeconomic rights in situations over which: it exercises authority or effective control; its acts or omissions bring about foreseeable effects on socioeconomic rights in other jurisdictions; or where a state, acting separately or jointly, is in a position to exercise decisive influence or to take measures to realise such rights (De Schutter et al. 2012, Principle 9).

State responsibility for preventing adverse human rights impacts from concealed tax-related IFFs from the Least Developed Countries can be assessed individually and collectively. The 
extraterritorial obligation to protect requires offshore states to take the necessary steps at a national level to prevent infringements of socioeconomic rights due to activities of private actors under their effective control (CESCR 2017, p. 30). However, the breadth of the global network of offshore states implicated in the concealment of international financial flows from the Least Developed Countries is such that overarching global tax transparency standards that reflect the needs and capacities of systemically disadvantaged low-income countries are necessary. As such, this chapter focuses on the obligations of international cooperation and assistance of states in a position to assist with the implementation of a human rights-based approach towards international tax transparency.

Article 2(1) of the Covenant sets out the expectation that states will take collective action to help fulfil the socioeconomic rights of persons outside their territories - by creating an international environment that enables the fulfilment of socioeconomic rights (CESCR 2017, pp. 36-37). The Maastricht Principles stipulate states must take all reasonable steps to ensure that organisations in which they participate act consistently with their state obligations (De Schutter et al. 2012, Principle 15). By virtue of the Organisation for Economic Cooperation and Development's (OECD) role as the de facto global tax standard setting body, its members are expected to take the steps necessary to prevent the adverse human rights impacts of tax-related IFFs that are attributable to Least Developed Countries not receiving the core transparency information needed to administer and enforce their revenue laws.

The practical implications of states' duties in this regard are laid out in the Maastricht Principles, which assert that in matters concerning the establishment of global regulatory standards, the extraterritorial obligations of states include the requirement to elaborate international tax standards in a manner consistent with their human rights obligations (De Schutter et al. 2012, Principle 17). The Committee on Economic, Social and Cultural Rights in calling for deeper international tax cooperation has acknowledged that providing excessive bank secrecy may affect the abilities of states where economic activities take place, to meet their obligation to mobilise the maximum available resources to implement socioeconomic rights (CESCR 2017). This human impact is particularly evident in the poorest countries with limited administrative capacities and meagre tax bases that increase their reliance upon taxation from HNWIs and MNEs.

Given that the primary duty-bearer of human rights obligations is the territorial state, the question arises whether ETOs are triggered when that state is unwilling or unable to meet its obligations; or whether ETOs are complementary (Askin 2019, p. 39)? In the case of the extraterritorial obligation to fulfil, it has been considered that they only arise when the territorial state is unwilling or unable to meet its obligations (Vandenhole and Benedek 2013, p. 335). The remainder of this chapter makes evident why it is that the Least Developed Countries are currently unable to detect concealed tax-related IFFs that drain their public revenues. This avoidable situation contributes to the most systemically disadvantaged low-income countries being unable to meet their obligations to fulfil core socioeconomic rights.

A systemic analysis of the standards that underpin existing international tax transparency frameworks demonstrates how they have marginalised Least Developed Countries, thereby allowing tax-related illicit financial outflows to remain concealed in a way that foreseeably effects socioeconomic rights. Relatedly, it shows that OECD nations are in fact in a position to exercise decisive influence or take measures to realise those rights - by implementing the type of international cooperation needed for the timely and methodical detection of tax-related IFFs from low-income countries unable to meet their human rights obligations. 


\section{International support for the Least Developed Countries}

The designation 'Least Developed Country' was established by the UN General Assembly in 1971 to provide special international support to low-income countries with 'severe structural handicaps to economic growth and development' (UNGA 1971). Thus far the principal support for Least Developed Countries has been duty-free and quota-free access to global markets, with supplemental development assistance as a stopgap measure before integration into the world economy. However, the generic structural transformation predicted by international trade theory has not materialised; with only five low-income countries graduating from Least Developed Country status over the last 50 years.

The most salient problems for the Least Developed Countries include a shortage of sustainable investment, deficiency of capital stock and scarce public revenues; with the external harms caused by tax havens, farm subsidies and immigration restrictions far outweighing the benefits of existing support measures (Gay 2018). Amongst their varied international support requirements, of particular importance are the needs for global governance mechanisms to address secrecy jurisdictions, dedicated global tax transparency assistance and dedicated assistance to improve domestic resource mobilisation capacity (Gay 2018). Yet, international assistance in these areas has been in short supply; with only $0.16 \%$ of total aid from OECD nations to African countries applied to domestic resource mobilisation programs in 2017 (OECD 2017c).

In his final report as Special Rapporteur on Extreme Poverty and Human Rights, Philip Alston described the persistence of global poverty as a 'political choice' (Alston 2020, p. 1). This dynamic has been particularly evident in the global responses to largely poverty-driven issues, such as infant mortality in low-income countries. Currently 1 in 14 children born in these countries die before their 5th birthday, from diseases that are largely preventable and treatable through simple and affordable interventions (World Health Organization 2019).

Such egregious human rights violations that are attributable to the want of basic healthcare require offshore states to address the ease with which tax-related IFFs can be concealed from the Least Developed Countries. Yet, two countervailing narratives impinge upon the political resolve to take decisive action to address such misuse of the international financial system. Accounts of dramatic progress towards poverty eradication in Africa driven by economic growth (Beegle and Christiaensen 2019) have been reinforced by the purported imperative for liberalised capital flows to hasten economic growth (International Monetary Fund 2019). Indeed in Africa, even human rights-based approaches to development have tended to premise the realisation of socioeconomic rights on the creation of economic growth (Vandenhole 2018, p. 657).

The narrative of progress towards poverty eradication is tied to the World Bank's international poverty line (IPL), which has been used to rationalise globalisation policies such as international capital mobility for developing countries. Yet, the IPL (currently $\$ 1.90$ per day) sets the bar so low as to all but guarantee the appearance of victory over global poverty. The standard of living established by the IPL is well below any reasonable conception of a life with dignity - and in the view of the Special Rapporteur is a world apart from the one set by human rights law (Alston 2020, p. 5).

With the impending arrival of SDG data on IFFs, a more robust poverty metric is needed to evaluate the human impact of international standards that sustain unchecked financial flows from the poorest countries. A promising alternative is the 'rights-based poverty line' that combines outcome indicators with the principle of country-specific poverty lines. For instance, this human rights-based benchmark reveals that a line 4.2 times higher than the IPL is required to achieve an infant mortality threshold of no more than 20/1000 lives (Woodward 2010, pp. 38-39). 


\section{International tax transparency and the Least Developed Countries}

The financial globalisation project has made tax information sharing between states crucial to the administration and enforcement of revenue laws. HNWIs and MNEs can evade or avoid domestic taxes easily, unless limited by concerted multilateral efforts (Neubig 2018, p. 1137). The two principal methods for tax information exchange between states are: exchange of information on request $(E O I R)$ where a specific application for information is made of a foreign tax authority; and the complementary post-Global Financial Crisis frameworks for automatic continuing exchange of prescribed information.

The former is facilitated through arrangements based on: the OECD Model Tax Convention on Income and on Capital (OECD 2017b, art. 26); the UN Model Double Taxation Convention Between Developed and Developing Countries (United Nations Department of Economic and Social Affairs (UNDESA) 2017 art. 26); and the OECD Model Agreement on Exchange of Information on Tax Matters (OECD 2002). The latter methods were designed by the OECD pursuant to a 2013 G20 mandate, and comprise the 2014 Standard for Automatic Exchange of Financial Account Information in Tax Matters (OECD 2017d); and Action 13 of the 2015 Final Report of the OECD/G20 Base Erosion and Profit Shifting Project (OECD 2015b). Albeit international tax cooperation has now been streamlined by the Multilateral Convention on Mutual Administrative Assistance in Tax Matters (OECD and the Council of Europe 2011, p. 5), automatic tax information sharing remains contingent upon some form of bipartite agreement between the competent authorities of individual states.

The EOIR standard has been the mainstay of international tax cooperation for most states since the 1960s. However, it has two significant limitations for under-resourced Least Developed Country revenue authorities: the specific information requested must be detailed on the basis of a clearly defined suspicion; and it requires them to reach bipartite agreements with the global network of offshore states. Revenue authorities in low-income countries generally lack the specific information required to initiate large-scale EOIR applications with multiple jurisdictions. To methodically detect tax-related IFFs Least Developed Countries require automatic tax information exchange with offshore states. Indeed, the automatic exchange process is said to enhance the 'means of production' of the information needed to combat cross-border tax evasion and avoidance (Ates 2020, p. 4).

The OECD's Global Forum on Transparency and Exchange of Information for Tax Purposes (Global Forum) requires participating states to ensure information on legal and beneficial ownership of relevant entities is available to their authorities (OECD 2016). However, they are not obliged to maintain ownership registers. The fact that under-resourced Least Developed Country revenue authorities are still obliged to submit an EOIR application to ascertain the beneficial ownership of offshore companies, trusts and foundations in most offshore states is a further serious obstacle to the methodical detection of illicit cross-border tax practices.

The OECD's 2014 standard for automatic exchange of information (AEOI) on the offshore wealth of non-residents requires reporting across three dimensions. It encompasses different types of investment income and capital; includes individuals and interposed legal entities; and applies to banks and financial institutions such as brokers and insurers (OECD 2017d, p. 12). The OECD's 2015 country-by-country reporting (CbC Reporting) standard requires MNEs with group incomes over $€ 750$ million to provide relevant governments with prescribed information in each tax jurisdiction where they do business. That information includes the amount of revenue, profit before income tax and income tax paid and accrued; and the number of employees, stated capital, retained earnings and tangible assets in each tax jurisdiction (OECD 2015b, p. 9). 
Yet, before a Least Developed Country can sign a Multilateral Competent Authority Agreement $(M C A A)$ to receive AEOI or CbC Reporting (under either a bilateral or multilateral treaty), it must prove compliance with extensive legal and administrative standards. It must also overcome the administrative burden of gathering, organising and sharing information for reciprocal exchange with authorities in offshore states. Minimum legal standards include domestic legislation with strong sanctions for breach of confidentiality obligations under tax treaties, whilst minimum administrative practices include security screening, revised employment contracts and ongoing training, together with strict infrastructure standards (OECD 2012, pp. 29-30).

These exacting standards do not reflect the needs and capacities of the Least Developed Countries. Typically, low-income countries have approximately one-tenth of revenue staffing of highincome countries (United Nations 2020, p. 40). The OECD's Global Forum has acknowledged developing countries face significant resource and political challenges in implementing its standards. Their resource challenges include a lack of human resources to translate standards into domestic laws; limited institutional capacity to handle exchanged data; inadequate finances for administrative and information technology infrastructures; and inadequate finances to collect domestic information for other jurisdictions (OECD 2017a), whilst the political challenges for developing countries include balancing the costs of implementing OECD mandated standards with domestic spending priorities; and taking on those with entrenched financial interests in the status quo (OECD 2017a).

Should a Least Developed Country government overcome these challenges, they face an additional legal hurdle before opening transparency pathways with the global network of offshore states. Automatic exchange relationships are only activated amongst jurisdictions that individually choose each other (OECD 2017d, p. 221). Should a Least Developed Country implement the prescribed laws and administrative practices, the MCAA does not come into effect until such time as a co-signatory notifies the Coordinating Body Secretariat that it intends to exchange information with that jurisdiction. Should the jurisdiction in which an ultimate parent entity resides decide not to activate an exchange relationship with that country, then it will not receive $\mathrm{CbC}$ information from the applicable foreign tax authority (Ates 2020, p. 18).

Even supposing a Least Developed Country were to surmount these regulatory barriers to securing automatic tax transparency, its authorities would face significant limitations in how they would be allowed to use the exchanged information. For instance, Section 5(2) of the Country-by-Country MCAA stipulates a CbC Report shall not be used as a 'substitute for a detailed transfer pricing analysis of individual transactions and prices based on a full functional analysis and a full comparability analysis' (OECD 2015a, p. 19). The independent BEPS Monitoring Group has described the OECD's continued insistence on a full functional analysis as inappropriate for developing countries that generally lack the technical capacity to apply such detailed investigations (BEPS Monitoring Group 2020, p. 3).

Consequently, the governments of the majority of people in extreme poverty lack the international cooperation needed to administer and enforce their revenue laws against those who transfer taxable income, capital and the proceeds of trade offshore. The international human rights obligations of OECD nations require them to take the necessary steps to bridge the gulf between their transparency standards and the legal and administrative capacities of the Least Developed Countries. The following section considers how the developmental concept of IFFs might support a differentiated approach towards tax information sharing.

\section{The developmental concept of illicit financial flows}

The developmental concept of illicit financial flows runs counter to the longstanding practice of rich nations prescribing the regulatory terms on which international capital holders engage 
with poor countries. Whilst not yet a legal term of art, IFFs have become a salient consideration for global economic policymakers and standard setting bodies. Although the OECD's lexicon of international transparency standards does not yet reference IFFs - the concept figures prominently in the Paris-based organisation's policy documents that deal with the imperative for domestic resource mobilisation in poor countries (OECD 2018).

The global agenda to address illicit financial flows was launched by African countries. Spurred by a determination to ensure accelerated and sustained development relying as much as possible upon domestic resources, the 2011 Conference of African Ministers of Finance, Planning and Economic Development issued the UN with a mandate to establish a High-Level Panel on Illicit Financial Flows from Africa. The High-Level Panel's core finding was that IFFs from Africa were large and increasing, with large commercial corporations the main culprits (UNECA 2015, p. 64). The policy implications of those findings were that urgent and coordinated action was needed to address the development impacts of tax losses and the opportunity costs of lost savings and investment in various sectors of African economies.

At the heart of the IFF concept is the universal recognition that taxation is the primary source of funding available to realise the SDGs. However, the High-Level Panel's findings also focused attention on the wider economic benefits African countries could have obtained, had international tax transparency standards sufficiently assimilated low-income countries. Instead, the systemic prioritisation of foreign investment over the mobilisation of domestic investment in poor countries has undercut a key economic benefit of international tax cooperation that should have been available to the private sector in Africa's Least Developed Countries.

Notably the global target to significantly reduce IFFs by 2030 (SDG 16.4) encompasses both illicit outflows and inflows. As such, it encompasses financial flows out of Least Developed Countries and financial flows into offshore states. The concept's core elements are that they must be: illicit in nature; cross national borders; and involve flows instead of stocks (United Nations Confernece on Trade and Development 2018). Given that illicit cross-border tax practices by MNEs make up the bulk of IFFs from developing countries, global policymakers have faced considerable conceptual, legal and practical challenges in determining whether this developmental concept should be extended from cross-border tax evasion, to include aggressive crossborder tax avoidance by MNEs.

The task of examining the conceptual and measurement challenges of IFFs has been assigned to SDG 16.4's joint custodians - the UN Office on Drugs and Crime and the UN Conference on Trade and Development (UNGA 2019). The joint custodians issued a Conceptual Framework for the Statistical Measurement of IFFs in October 2020 that distinguished four main categories of IFFs. Relevant for the purposes of this chapter is the category of "illicit tax and commercial IFFs" which they divided into two components: illegal tax and commercial IFFs; and flows generated from legal economic activities through aggressive tax avoidance. This broad-based approach to strategic cross-border tax planning by MNEs could have significant implications for addressing the human rights impacts of concealed tax-related IFFs from lowincome countries.

The opportunity to bring those MNE cross-border practices that exist in a grey area between tax evasion and purportedly legal tax avoidance, under the developmental rubric of illicit financial flows, signals an important synergy between the 2030 Agenda's political processes and the creation of an international environment that enables the fulfilment of socioeconomic rights in the Least Developed Countries - by ensuring they receive the core transparency information needed to administer and enforce their revenue laws. Currently, the 2030 Agenda's system of Voluntary National Reviews does not provide a robust process for monitoring global targets such as SDG 16.4. That said, there is scope to be address this limitation by repositioning its 
High-level Political Forum more firmly into the UN General Assembly machinery, as was the case with the Human Rights Council (Adams 2019, p. 36).

\section{A human rights-based approach towards international tax transparency}

In extolling the purported benefits of the EOIR framework, the OECD's Global Forum recently used the 'Butterfly Effect' metaphor to claim that in the fight against IFFs small changes can make big differences to African states seeking to improve domestic resource mobilisation (Manatta 2020). Notwithstanding that Edward Lorenz's notion that the flap of a butterfly's wings in Brazil might set off a tornado in Texas speaks to the unpredictability of chaos theory, it seems most unlikely that the limited benefits of EOIR will address the wide-ranging systemic misuse of the international financial system that drains the public revenues of the Least Developed Countries. Whilst it remains unclear precisely what the international human rights law obligation of international cooperation and assistance entails (Askin 2019, p. 37), this solemn state responsibility cannot be said to be met by small steps towards the multilateral action needed to detect tax-related IFFs from the Least Developed Countries.

To date, international support for Least Developed Countries has largely neglected their manifest need for assistance to address the human rights impacts of unchecked international financial flows. As of the end of 2019, the OECD's AEOI and CbC Reporting reforms had failed to make any automatic tax-related information available to the 46 Least Developed Countries (United Nations 2020, p. 44). Albeit there have been stop gap measures such as Tax Inspectors Without Borders program that operates with a global roster of 50 tax audit experts (OECD and UNDP 2019); such initiatives clearly lack the resources (and the legal frameworks) to deal with the scale of tax-related IFFs from Africa.

The limited progress towards an inclusive system of international tax cooperation that makes its benefits are available to all countries has led to increasing misgivings regarding the role of the de facto global tax standard setting body. Most notably, in March 2020, the UN General Assembly launched the High-level Panel on International Financial Accountability, Transparency and Integrity for Achieving the 2030 Agenda, tasked with identifying gaps, impediments and vulnerabilities in the design and implementation of international institutional and legal financial transparency frameworks (Presidents of the UN General Assembly and the Economic and Social Council 2020). The FACTI Panel issued a final report in February 2021 in which they concluded IFFs were a systemic problem requiring a systemic solution, making 14 Recommendations including inter alia a call to end asymmetries in relation to information shared for tax purposes so that all countries can receive information (UN FACTI Panel 2021).

Although tackling cross-border tax avoidance is now received international development policy (Beegle and Christiaensen 2019, p. 1), the practical question of how to deal with such practices from poor countries persists. The 2030 Agenda provides an important segue into operationalising the ETOs of states in a position to assist with the fiscal scrutiny of international financial flows from systemically disadvantaged low-income countries - whose transparency needs are different to those of OECD nations.

By way of illustration, the OECD's CbC Reporting standards imposed a $€ 750$ million group income threshold, below which there are no automatic disclosure requirements for MNEs. This group income threshold captures the bulk of cross-border trade, but it excludes the vast majority of MNEs. Whilst the impacts of the OECD setting such a high-income level are limited for its members with small corporate tax bases, that is not the case for Least Developed Countries which tend to rely heavily upon corporate income tax from foreign investors. Should such 
a country eventually manage to activate a CbC Reporting relationship with a corporate tax haven, it is likely to apply to only a limited number of MNEs.

Such incompatibilities, together with the gulf in the legal and administrative capacities of revenue authorities in Least Developed Countries and OECD nations, necessitate a differentiated system of international tax transparency. That said, reform to prevent the adverse human rights impact of tax-related IFFs from Least Developed Countries must balance the imperative for urgent action in countries facing intensifying extreme poverty, with the ideological commitment of OECD nations to financial privacy and confidentiality for non-residents.

The extensive interest in initiatives such as Tax Inspectors Without Borders that seek to bridge capacity gaps in developing countries provides an auspicious precedent for reform in this crucial area of global economic governance. The widely acknowledged legal and administrative deficits of Least Developed Country revenue authorities in subjecting international financial flows to methodical fiscal scrutiny justify expanding the scale of technical assistance made available to these systemically disadvantaged low-income countries in the short-to-medium term.

Having regard to the foregoing, this chapter concludes by outlining one possible reform pathway that builds on the type of reporting requirements established by the OECD's Financial Action Task Force (FATF 2012). A differentiated transparency framework would integrate jurisdictions that exceed a specified annual volume of cross-border financial services to nonresidents. It would require law, accounting and corporate service professionals in those jurisdictions to collate prescribed information from clients connected to international financial transfers from Least Developed Countries that exceed a prescribed value.

That prescribed information, together with AEOI and CbC Reporting information, would then be analysed by a global panel of independent tax experts under the auspices of a jointly funded UN/OECD secretariat. The panel's objective would be to identify international financial flows by persons and entities in respect of whom there is prima facie evidence of cross-border tax practices involving illegal tax and commercial IFFs or IFFs from aggressive tax avoidance (as set out in the Conceptual Framework) with the objective of concealing revenues and reducing tax burdens through evading controls and regulations. The details of any prima facie tax-related IFFs identified by the panel would then be transmitted through a global transparency register.

This type of differentiated approach towards producing the information needed to combat cross-border tax evasion and aggressive tax avoidance from the Least Developed Countries would maintain existing offshore confidentiality standards for residents of the majority of countries, and would impact approximately $1 \%$ of global trade. To be sure, a human rights-based approach towards international tax cooperation would require the renegotiation of bilateral and multilateral agreements, and the amendment of ancillary national laws.

Whilst such reform would raise sovereignty issues, it is noted that the OECD was able to overcome similar issues when it implemented its 2014-2015 automatic tax transparency reforms. Moreover, it could be argued that offshore states' ETOs to protect require them to implement differentiated global tax transparency standards designed to prevent infringements by private actors of the socioeconomic rights of those living in systemically disadvantaged low-income countries.

\section{Conclusion}

Implementing international transparency standards that can accommodate the needs and capacities of the Least Developed Countries is first and foremost a political process, not a technical one. The leading standards for tax information exchange between states have been shaped by the OECD's ideological commitment to liberalised capital flows as a prerequisite for the economic growth required for national development. Yet, under existing global frameworks, when 
economic growth has occurred in Africa, it has generally not led to significant poverty reduction. Indeed, using the very low standard of the World Bank's IPL, and assuming a return to pre-Global Financial Crisis growth levels, it is estimated that the eradication of poverty will take at least 100 years (Woodward 2015).

Since the launch of the financial globalisation project in Africa in the 1980s, progress towards securing core transparency information for the countries least likely to fulfil their human rights obligations has been piecemeal, at best. However, the universal human rights obligations undertaken half a century ago in the wake of the last great global upheaval could provide a legal basis on which to challenge the enduring failure of global economic policymakers to implement the international tax cooperation needed to address the haemorrhaging of public revenues from Africa's poorest countries. At the same time, there is now a novel political setting in which to evaluate the human impacts of international tax standards that are conducive to the continuing concealment of tax-related IFFs from low-income countries with severe structural handicaps.

Over 30 years have now passed since renowned African novelist Chinua Achebe accepted an invitation to attend the OECD headquarters in Chateau de la Muette to listen to Western bankers and economists preach the virtues of structural adjustment and market discipline in Africa. They urged Achebe and other invited Africans to trust in their expertise, and most of all to be patient. He was left in no doubt regarding the self-assurance of these experts - they were 'the masters of our world, savouring the benefits of their success' (Achebe 2009, p. 40). Yet, when the time eventually came for Achebe to respond to their insistence on African forbearance, he demanded of the illuminati of neoliberalism - 'would you recommend a similar remedy to your own people, and your own governments' (Achebe 2009, p. 42).

\section{References}

Achebe, C. (2009) Africa's Tarnished Name, Penguin Random House.

Adams, B. (2019) Democratic Global Governance: If It Doesn't Challenge Power It Isn't Democratic. Reshaping Governance for Sustainability, Global Civil Society Report.

Alston, P. (2020) The Parlous State of Poverty Eradication: Report of the Special Rapporteur on Extreme Poverty and Human Rights, Human Rights Council.

Alston, P. and Reisch, N. (2019) Tax, Inequality and Human Rights, Oxford, Oxford University Press.

Askin, E. (2019) 'Economic and Social Rights, Extraterritorial Application' in Wolfrum, R. and Ruiz Fabri, H. (eds). Max Planck Encyclopedias of International Law, Oxford Public International Law.

Ates, L. (2020) 'Tax Information Production, Sharing, Use and Publication' FACTI Panel Background Paper, UNDESA.

Beckett, P. (2018) Tax Havens and International Human Rights, Routledge.

Beegle, K. and Christiaensen, L. (2019) Accelerating Poverty Reduction in Africa, World Bank.

BEPS Monitoring Group (2020) Submission to the Inclusive Framework on BEPS on the Public Consultation Document: Review of Country by Country Reporting.

Committee on Economic, Social and Cultural Rights (CESCR) (2017) General Comment 24 on State Obligations Under the Internaitonal Covenant on Economic, Social and Cultural Rights in the Context of Business Activities, E/C.12/GC/24.

De Schutter, O. et al. (2012) 'Commentary to the Maastricht Principles on Extraterritorial Obligations of States in the Area of Economic, Social and Cultural Rights', Human Rights Quarterly 34, 1084-1069.

De Zayas, A.-M. (2016) Promotion of a Democratic and Equitable International Order. Promotion and Protection of Human Rights: Human Rights Questions, Including Alternative Approaches for Improving the Effective Enjoyment of Human Rights and Fundamental Freedoms, UN General Assembly.

Etter-Phoya, R., Lima, S. and Meinzer, M. (2019) Corporate Income Taxation in the Digital Age: Africa in the Corporate Tax Haven Index 2019, Tax Justice Network. 
Financial Action Task Force (FATF) (2012-2018) International Standards on Combating Money Laundering and the Financing of Terrorism \& Proliferation, FATF.

Gay, D. (2018) 'International Support for Least Developed Countries:A Different Way', https://www.un.org/ ldcportal/international-support-for-the-least-developed-countries-a-different-way/ [Accessed 21.9.21].

Global Forum on Transparency and Exchange of Informaiton for Tax Purposes (2020) Tax Transparency in Africa 2020: Africa Initiative Progress Report 2019, OECD.

Higgins, R. (1995) Problems and Process: International Law and How We Use It, Clarendon.

Independent Commission for the Reform of International Corporate Taxation (2019) A Roadmap for a Global Asset Registry: Measuring and Tackling Inequality; Curbing Tax Avoidance, Tax Evasion, Corruption and Illicit Financial Flows.

International Bar Association (2013) Tax abuses, Poverty and Human Rights, Cambrian Printers.

International Monetary Fund (2019) Regional Economic Outlook Sub-Saharan Africa: Navigating Uncertainty, IMF.

Kharas, H. and Hamel, K. (2018) 'The Start of a New Poverty Narrative', https://brookings.edu/blog/ future-development/2018/06/19/the-start-of-a-new-poverty-narrative/ (Accessed 21.9.21).

Manatta, Z. (2020) 'Exchange of Tax Information: A Butterfly Effect on Domestic Resource Mobilisation', Development Matters, http://oecd-development-matters.org (Accessed 21.9.21).

Neubig, T. (2018) Global Tax Administration Initiatives Addressing Tax Evasion and Avoidance, Tax Notes International.

Norwegian Government Commission (2009) Tax Havens and Development: Status, Analyses and Measures, Department of Government Publications.

Organisation for Economic Co-operation and Development (OECD) (2002) Model Agreement on Exchange of Information in Tax Matters, OECD Publishing.

OECD (2012) Keeping it Safe:The OECD Guide on the Protection of Confidentiality of Information Exchanged for Tax Purposes, OECD Publishing.

(2015a) Action 13: Country-by-Country Reporting Implementation Package, OECD Publishing.

(2015b) Transfer Pricing Documentation and Country-by-Country Reporting Action 13: 2015 Final Report OECD G20 Base Erosion and Profit Shifting Project, OECD Publishing.

(2016) Global Forum on Transparency and Exchange of Information for Tax Purposes: 2016 Terms of Reference to Monitor and Review Progress Towards Transparency and Exchange of Information on Request for Tax Purposes, OECD Publishing.

(2017a) 'The Global Forum's Plan of Action for Developing Countries Participation in AEOI' in Global

Forum (ed). Global Forum on transparency and exchange of informaiton for tax purposes, OECD Publishing.

(2017b) Model Tax Convention on Income and on Capital: Condensed Version, OECD Publishing.

(2017c) Revenue Statistics in Africa, OECD Publishing.

(2017d) Standard for Automatic Exchange of Financial Account Information in Tax Matters, Second Edition ed., OECD Publishing.

(2018) Illicit Financial Flows:The Economy of Illicit Trade in West Africa, OECD Development Centre.

OECD and Council of Europe (2011) The Multilateral Convention on Mutual Administrative Assistance in Tax Matters: Amended by the 2010 Protocol, OECD Publishing.

OECD and UNDP (2019) Tax Inspectors Without Borders Annual Report 2019. OECD/UNDP.

Peters, A. (2018) 'Global Constitutionalism:The Social Dimension' in Suami, T., Peters, A. and Vanoverbeke, D. (eds). Global Constitutionalism from European and East Asian Perspectives, Cambridge University Press.

Presidents of the General Assembly and the Economic and Social Council (2020) Terms of Reference HighLevel Panel on International Financial Accountability, Transparency and Integrity for Achieving the 2030 Agenda, United Nations.

UN Conference on Trade and Development (UNCTAD) (2018) Report of the Second Expert Meeting on the Statistical Measurement of Illicit Financial Flows.

UNCTAD and UNODC (2020) Conceptual Framework for the Statistical Measurement of Illicit Financial Flows;Vienna; United Nations.

UN High Level Panel on International Financial Accountability, Transparency and Integrity for Achieving the 2030 Agenda (2021) Financial Integrity for Sustainable Development; United Nations. 
United Nations Department of Economic and Social Affairs (UNDESA) (2017) United Nations Model Double Taxation Convention Between Developed and Developing Countries: 2017 Update, United Nations. (2018) Metadata Indicator SDG 16.4.1, UN Statistics Division.

United Nations Economic Commission for Africa (UNECA) (2015) Illicit Financial Flows: Report of the High Level Panel on Illicit Financial Flows From Africa. Addis Baba, United Nations.

United Nations General Assembly (UNGA) (1971) 'Identification of the least developed among the developing countries', Resolution adopted by the General Assembly on 18 November 1971, A/ RES/26/2768.

(2015) 'Transforming our world: The 2030 agenda for sustainable development', Resolution adopted by the General Assembly, A/RES/70/1.

(2019) Report of the Secretary General: International Financial System and Development Macroeconomic Policy Questions, United Nations.

UN High Level Panel on International Financial Accountability, Transparency and Integrity for Advancing the 2030 Agenda (UN FACTI Panel) (2021) Financing for Sustainable Development, United Nations.

United Nations (UN) (1966) International Covenant on Economic, Social and Cultural Rights. Adopted and Opened for Signature, Ratification and Accession by General Assembly Resolution 2200A (XXI).

(2015) Addis Ababa Action Agenda of the Third Conference on Financing for Development, UNDESA.

(2020) Inter-Agency Task Force on Financing for Sustainable Development: 2020 Financing for Sustainable Development Report.

Vandenhole, W. (2018) 'De-Growth and Sustainable Development: Rethinking Human Rights Law and Poverty Alleviation', Law and Development Review 11, 647-675.

Vandenhole, W. and Benedek, W. (2013) 'Extraterritorial Human Rights Obligations and the North-South Divide' in Langford, M., Vandenhole, W., Scheinin, M. and Van Genugten, W. (eds). Global Justice, State Duties: The Extraterritorial Scope of Economic, Social and Cultural Rights in International Law, Cambridge University Press.

Woodward, D. (2010) How Poor is 'Poor'? Towards a Rights-Based Poverty Line, New Economics Foundation. (2015) 'Incrementum ad Absurdum: Global Growth, Inequality and Poverty Eradication in a Carbon-Constrained World', World Social and Economic Review of Contemporary Policy Issues 4.

World Health Organisation (2019) World Health Statistics 2019: Monitoring Health for the Sustainable Development Goals.

Zucman, G. (2015) The Hidden Wealth of Nations: The Scourge of Tax Havens, University of Chicago Press. 